\title{
Effect of Biofertilizer, Herbicide Application and Nitrogen Management on Growth, Productivity of Wheat (Triticum aestivum L.)
}

\author{
Deepa*, Y.V.Singh and Suruchi Tyagi
}

Agricultural Research Farm, Indian Agricultural Research Institute, New Delhi 110012, India

*Corresponding author

\section{Keywords}

Biofertilizer,

Herbicide,

Application,

Nitrogen,

Management,

Wheat,

Triticum aestivum

Article Info

Accepted:

20 March 2019

Available Online:

10 April 2019

\section{A B S T R A C T}

A field experiments was conducted during winter seasons of 2014-15 and 2015-16 at the Agricultural Research Farm, Indian Agricultural Research Institute, New Delhi to study the effect of biofertlizer, herbicides, nitrogen management on crop growth and yield of wheat. The treatment consisted of two biofertilizer viz. No biofertilizer and Azotobacter, two levels of herbicides, viz. no herbicide, Clodinafop-propargyl application in main plot and three times of nitrogen application, viz. Chemical fertilizer (recommended dose of urea), Natural fertilizer + chemical fertilizer (50:50) and Natural fertilizer +chemical fertilizer (25:75) in sub plot treatment, respectively. Inoculation of Azotobacter resulted higher growth attributes, yield attributes, seed yield. Significantly higher value plant height was recorded under Azotobacter inoculated as compared to uninoculated. Dry matter accumulation was higher with Azotobacter inoculated than uninoculated plants. The highest value of these attributes was recorded with the application of Azotobacter which was significantly higher that the control (No biofertilizer) in present experimentation. Inoculation of Azotobacter resulted higher number of grains per spike (58.06 and 60.85) and grain weight (6.71 and $6.89 \mathrm{~g}$ ) which was significantly more than uninoculated plants. The 1000 seed weight of wheat significantly increased with the application of Azotobacter. The highest seed yield (45.77 and $46.72 \mathrm{q} / \mathrm{ha}$ ) was recorded with Azotobacter application which was significantly higher than uninoculated control (38.98 and $46.72 \mathrm{q} / \mathrm{ha}$ ) during 2014-15 and 2015-16, respectively. Similarly straw, biological yield and harvest index of the crop was also improved significantly with Azotobacter application as compared to control. The growth attributes i.e. plant height and dry matter accumulation were found higher in Clodinafop - Propargyl $60 \mathrm{~g} \mathrm{ha}^{-1}$ at 30 DAS while least growth attributes was recorded under untreated control during both the years. The treated plots exhibited significantly higher number of grains per spike (57.14 and 59.87), grain weight per spike (7.05 and $7.23 \mathrm{~g}$ ) and 1000-grain weight than no weedicide control during respective years. The application of Clodinafop Propargyl $60 \mathrm{~g} \mathrm{ha}^{-1}$ at 30 produced significantly higher (45.15 and $46.62 \mathrm{q} / \mathrm{ha}$ ) grain yield than untreated plots (36.59 and $40.57 \mathrm{q} / \mathrm{ha}$ ). The nitrogen applied through urea or it was applied in combination with natural sources such as FYM had significant improvement on growth attributes and recorded higher plant height with $25 \% \mathrm{~N}$ applied through natural fertilizer $+75 \%$ nitrogen applied through urea recorded higher plant height than the other fertility treatments over the nitrogen applied through 50\% natural $+50 \% \mathrm{~N}$ applied through Urea. The combined application of $75 \% \mathrm{~N}$ by urea along with $25 \%$ natural fertilizer increased the number of effective tillers $\mathrm{m}^{-2}$, number of grains per spike, length of spike and the test weight. The combined application of $25 \% \mathrm{~N}$ applied by natural fertilizers $+75 \mathrm{~N}$ through urea + micronutrients registered highest (44.47 and $45.94 \mathrm{q} / \mathrm{ha}$ ) grain yield of wheat during 2014-15

\section{Introduction} natural $+50 \%$ through urea fertilizers were applied. 
Wheat is the most important cereal crop which is badly infested with grassy as well as broad-leaf weeds. Since 1982 isoproturon is most widely used herbicide for management of Phalaris minor in wheat, particularly under rice-wheat cropping system. But, its efficacy has declined due to development of resistance in P. minor. However, the sole dependence on herbicide of single mode of action is also not advisable as it has contributed to shift towards difficult to control weeds and rapid evolution of multiple herbicides resistance, which is a threat to wheat production (Singh 2007).

Therefore, there is need to use mixture of herbicides in a way to lower the load on environment and improve weed control efficacy without any adverse effect on crop. Nitrogen $(\mathrm{N})$ is the nutrient that most often limits crop production. Among major cereals, wheat requires $1 \mathrm{~kg}$ of $\mathrm{N}$ to produce $44 \mathrm{~kg}$ of wheat (Pathak et al., 2003). Generally, more than $50 \%$ of the $\mathrm{N}$ applied is not assimilated by plants. Significant interaction between herbicide and nitrogen, where increased nitrogen found to enhance the performance of herbicide as well as $\mathrm{N}$-scheduling not only influences the crop growth but also influences weed density and biomass also (Kim et al., (2006). However, information in this regard is lacking. So, there is a greater need for new formulated herbicides with nitrogen rates and time of application to make out the effect of treatments on growth and yield of wheat.

\section{Materials and Methods}

The Field experiment was conducted on a field site during Rabi seasons for two consecutive years of 2014-15 and 2015-16 at the Agricultural Research Farm, Indian Agricultural Research Institute, New Delhi 110012, $\left(28^{\circ} 38^{\prime} \mathrm{N}, 7^{\circ} 11 \mathrm{E}, 228.6 \mathrm{~m}\right.$ above sea level) to study the Effect of nitrogen management and herbicide (Clodinafoppropargyl) on growth and yield of wheat in split plot design with three replications. The soil of the experimental field was sandy-loam in texture, low in organic carbon $(0.542 \%)$, available nitrogen $(159.90 \mathrm{~kg} / \mathrm{ha})$ and available phosphorus $(10.63 \mathrm{~kg} / \mathrm{ha})$ contents while was medium in available potassium (168.73 kg/ha).

The soil reaction was near neutrality with slight alkaline tendency. The treatment consisted of two biofertilizer viz. No biofertilizer and Azotobacter, two levels of herbicides, viz. no herbicide, Clodinafoppropargyl application in main plot and three times of nitrogen application, viz. Chemical fertilizer (recommended dose of urea), Natural fertilizer + chemical fertilizer (50:50) and Natural fertilizer +chemical fertilizer (25:75) in sub plot treatment, respectively. Wheat variety 'HD-2967' was sown on 21 November, 2014 and 20 November, 2015 with $125 \mathrm{~kg}$ seed/ha by keeping row to row spacing of $22.5 \mathrm{~cm}$ during both the years of investigations, respectively.

The wheat seed used for sowing the plots receiving biofertilizer treatment was inoculated with Azotobacter obtained from the Division of Microbiology, IARI, New Delhi. Nitrogen applied as per treatment but full amount of $\mathrm{P}$ and $\mathrm{K}$ were applied at the time of sowing. Herbicides were dissolved in 600 liters water and applied at 30 days after sowing (DAS), using the knapsack sprayer fitted with flat fan nozzle.

Observations were recorded on growth, yield attributes and grain and straw yield as per standard procedure. Grain yield recorded in $\mathrm{kg} /$ plot was finally converted into grain yield $\mathrm{kg} / \mathrm{ha}$. All data were put to analysis of variance as described by Gomez and Gomez (1984). The mean assessment was accomplished by least significant difference (LSD) at 5\% level of probability. 


\section{Results and Discussion}

\section{Effect on plant growth}

The application of Azotobacter brought about significant improvement in term of plant height and dry matter accumulation in both years of experimentation. Significantly higher value plant height was recorded under Azotobacter inoculated as compared to uninoculated. Dry matter accumulation was higher with Azotobacter inoculated than uninoculated plants. It may also be noted that not only accumulation of dry matter was increased due to the effects of Azotobacter application, but translocation of dry matter as well as its efficiency were also found to be higher in crop plants applied Azotobacter as compared to control. Thus, improvement in plant height, dry matter accumulation is sufficient to indicate that dry matter partitioning was favorably influenced by Azotobacter application. The growth attributes i.e. plant height and dry matter accumulation were found higher in Clodinafop - Propargyl $60 \mathrm{~g} \mathrm{ha}^{-1}$ at 30 DAS while least growth attributes was recorded under untreated control during both the years. Plant height and dry matter accumulation in wheat crop were significantly higher in treated with Clodinafop - Propargyl $60 \mathrm{~g} \mathrm{ha}^{-1}$ at as compared to that of untreated during both the years. The application of nitrogen through natural sources and chemical sources i.e. urea either in isolation or in combination had significant effect on the growth of wheat crop (Table 1). The nitrogen applied through urea or it was applied in combination with natural sources such as FYM had significant improvement on growth attributes and recorded higher plant height with $25 \% \mathrm{~N}$ applied through natural fertilizer $+75 \%$ nitrogen applied through urea recorded higher plant height than the other fertility treatments over the nitrogen applied through 50\% natural $+50 \% \mathrm{~N}$ applied through Urea. This might have resulted from the higher availability of nutrients and also the better growing conditions in the root zone created by the organic manures applied to the wheat crop. The higher plant height recorded in treatment receiving combined application $75 \% \mathrm{~N}$ by Urea $+25 \%$ by natural fertilizer had favourable impact on the dry matter accumulation by wheat and resulted in higher dry matter accumulation at all observational stages than the treatments receiving only $\mathrm{N}$ by urea or $50 \%$ by Urea $+50 \%$ by natural fertilizers. The higher dry weight of wheat could have been achieved through production of more number of tillers owing to the availability of all the nutrients especially nitrogen. The beneficial effect of $\mathrm{N}$ through fertilizers on growth of wheat had been reported earlier by many workers i.e. Singh $e t$ al., (2011) and Tejalben et al., (2017).

\section{Effect on yield and yield attributes}

The application of Azotobacter brought significant improvements in yield attributes like spike length, spike weight, number of grains per spike, seed weight per plant and 1000 seed weight. The highest value of these attributes was recorded with the application of Azotobacter which was significantly higher that the control (No biofertilizer) in present experimentation. Inoculation of Azotobacter resulted higher number of grains per spike (58.06 and 60.85) and grain weight (6.71 and $6.89 \mathrm{~g}$ ) which was significantly more than uninoculated plants. The 1000 seed weight of wheat significantly increased with the application of Azotobacter. The lowest 1000 seed weight was recorded in control. Since seed size and protein content of particular genotypes are genetically-controlled characters, therefore such traits cannot be manipulated when the crop is grown under relatively high input condition. However, under control condition, reduction in seed size and protein content from the potential value 
of any particular genotype can be offset by biofertilizer application, which is very cost effective and is unique $\mathrm{N}$-source that enters the plant system very quickly and effectively. Barik and Goswami, (2003) reported that use of $75 \% \mathrm{RDN}$ (100 kg N ha-1 RDH) along with Azotobacter seed inoculation showed at par results of yield attributes (effective tillers $/ \mathrm{m}^{2}$, ear length and grains per ear) and yield.

The seed, straw and biological yield of wheat enhanced significantly with the application of Azotobacter. The highest seed yield (45.77 and $46.72 \mathrm{q} / \mathrm{ha}$ ) was recorded with Azotobacter application which was significantly higher than uninoculated control (38.98 and $46.72 \mathrm{q} / \mathrm{ha}$ ) during 2014-15 and 2015-16, respectively. Similarly straw, biological yield and harvest index of the crop was also improved significantly with Azotobacter application as compared to control. The higher value of yield attributing characters and finally yield of wheat was found due to application of Azotobacter indicating the synergistic effect of the micro organisms. Similar results confirm by Gawali et al., (2018).

The application of post emergence of Clodinafop - Propargyl $60 \mathrm{~g} \mathrm{ha}^{-1}$ at 30 DAS recorded significantly higher number of spikes $\mathrm{m}^{-2}$, number of grains per spike and 1000 grain weight than weedy check during both the years. The treated plots exhibited significantly higher number of grains per spike (57.14 and 59.87), grain weight per spike (7.05 and $7.23 \mathrm{~g}$ ) and 1000-grain weight than no weedicide control during respective years. Shezad et al., (2012) and Hamada et al., (2013) confirms that the application of post-emergence Clodinafop-Propargyl formulations for controlling annual grassy weeds in wheat fields increased length of spike $(\mathrm{cm})$, weight of spike $(\mathrm{g})$, weight of 1000 grain $(\mathrm{g})$, number of spikelet spike $^{-1}$, number of grains spike ${ }^{-1}$ and wheat grain and straw yields $\left(\mathrm{kg} \mathrm{plot}^{-1}\right)$. Wheat yield was affected remarkably by the weeds as in the present investigation. Uncontrolled weeds on an average caused 12.31 and 12.61 per cent reduction in the yield during 2014-15 and 2015-16, respectively as compared to post emergence application of clodinafoppropargyl. The reduction of wheat yield due to weed infestation amounted $30.7 \%$ to $61 \%$ compared to weed-free control. Fenoxaprop and clodinafop-propargyl were most effective in controlling Phalaris minor and A. fatua with maximum mortality of 86.76 and $85.52 \%$, respectively. The application of Clodinafop - Propargyl $60 \mathrm{~g} \mathrm{ha}^{-1}$ at 30 produced significantly higher grain yield than untreated plots. Bharat and Karchroo (2007) also reported superiority of tank mixing of clodinafop + metsulfuron methyl over isoproturon alone in broadening the spectrum of weed control and increasing yield. Malik et al., (2013) found clodinafop $0.06 \mathrm{~kg} / \mathrm{ha}$ very effective (95-98\%) only against grassy weeds. clodinafop- propargyl + metsulfuron- methyl being at par with clodinafop $f b$ metsulfuron 0.06 and $0.004 \mathrm{~kg} / \mathrm{ha}$ recorded the number of spikes, 1000-grain weight and grain yield of wheat statistically similar to that of weed free check.

The combined application of $75 \% \mathrm{~N}$ by urea along with $25 \%$ natural fertilizer increased the number of effective tillers $\mathrm{m}^{-2}$, number of grains per spike, length of spike and the test weight. The enhanced early vegetative growth in terms of higher dry matter accumulation and vigorous root system resulted in more number of tillers $\mathrm{m}^{-2}$ which consequently increased the number of ear bearing tillers significantly. The combined application of $75 \% \mathrm{~N}$ by urea along with $25 \%$ natural fertilizer also increased the number of grains per ear and test weight. However, in case of test weight, the treatment difference lacked significance including control (Table 2). 
Table.1 Plant height, dry matter accumulation and yield attributes as influenced by biofertilizer, weed control and nitrogen management

\begin{tabular}{|c|c|c|c|c|c|c|c|c|c|c|}
\hline \multirow[t]{2}{*}{ Treatments } & \multicolumn{2}{|c|}{ Plant height $\quad(\mathrm{cm})$} & \multicolumn{2}{|c|}{$\begin{array}{c}\text { Dry matter } \\
\text { accumulation } \\
\text { (g/plant) }\end{array}$} & \multicolumn{2}{|c|}{$\begin{array}{l}\text { Effective tillers } \\
\qquad\left(\mathbf{m}^{2}\right)\end{array}$} & \multicolumn{2}{|c|}{ Spike length (cm) } & \multicolumn{2}{|c|}{ Spike weight (g) } \\
\hline & 2014-15 & $2015-16$ & $2014-15$ & $2015-16$ & $2014-15$ & $2015-16$ & $2014-15$ & $2015-16$ & $2014-15$ & $2015-16$ \\
\hline \multicolumn{11}{|l|}{ Biofertilizer } \\
\hline No biofertilizer & 96.82 & 98.35 & 1572.23 & 1590.83 & 358.27 & 363.51 & 9.67 & 9.07 & 2.77 & 2.98 \\
\hline Azotobacter application & 102.40 & 103.51 & 1652.75 & 1688.58 & 364.75 & 373.40 & 10.52 & 10.60 & 3.12 & 3.29 \\
\hline S.Em. $( \pm)$ & 0.53 & 0.70 & 3.39 & 5.19 & 0.57 & 0.61 & 0.05 & 0.06 & 0.02 & 0.02 \\
\hline CD at $5 \%$ & 1.82 & 2.41 & 11.71 & 17.92 & 1.97 & 2.55 & 0.16 & 0.17 & 0.06 & 0.07 \\
\hline \multicolumn{11}{|l|}{ Weedicide application } \\
\hline No weedicide & 98.24 & 99.57 & 1590.72 & 1606.09 & 355.31 & 359.40 & 9.94 & 9.53 & 2.81 & 3.06 \\
\hline $\begin{array}{l}\text { Clodinafop-propargyl } \\
\text { application }\end{array}$ & 100.97 & 102.29 & 1634.25 & 1673.32 & 367.71 & 377.50 & 10.25 & 10.15 & 3.08 & 3.21 \\
\hline S.Em. $( \pm)$ & 0.53 & 0.70 & 3.39 & 5.19 & 0.57 & 0.61 & 0.05 & 0.06 & 0.02 & 0.02 \\
\hline CD at $5 \%$ & 1.82 & 2.41 & 11.71 & 17.92 & 1.97 & 2.55 & 0.16 & 0.17 & 0.06 & 0.07 \\
\hline \multicolumn{11}{|l|}{ Nitrogen management } \\
\hline $100 \%$ though Urea & 100.45 & 101.83 & 1632.63 & 1661.62 & 364.66 & 371.67 & 10.19 & 10.12 & 2.96 & 3.19 \\
\hline $\begin{array}{l}\mathbf{5 0 \%} \text { Natural fertilizer + } \\
\mathbf{5 0 \%} \text { Urea }\end{array}$ & 95.91 & 96.89 & 1529.29 & 1550.12 & 347.12 & 351.38 & 9.80 & 9.13 & 2.77 & 2.84 \\
\hline $\begin{array}{l}25 \% \text { Natural fertilizer + } \\
75 \% \text { Urea }\end{array}$ & 102.46 & 104.06 & 1675.54 & 1707.38 & 372.75 & 382.31 & 10.30 & 10.27 & 3.10 & 3.37 \\
\hline S.Em. $( \pm)$ & 1.06 & 0.94 & 7.08 & 7.68 & 1.81 & 2.23 & 0.11 & 0.10 & 0.03 & 0.03 \\
\hline CD at $5 \%$ & 3.17 & 2.81 & 21.05 & 23.04 & 5.41 & 6.89 & 0.33 & 0.31 & 0.09 & 0.10 \\
\hline
\end{tabular}


Table.2 Yield and yield attributes as influenced by biofertilizer, weed control and nitrogen management

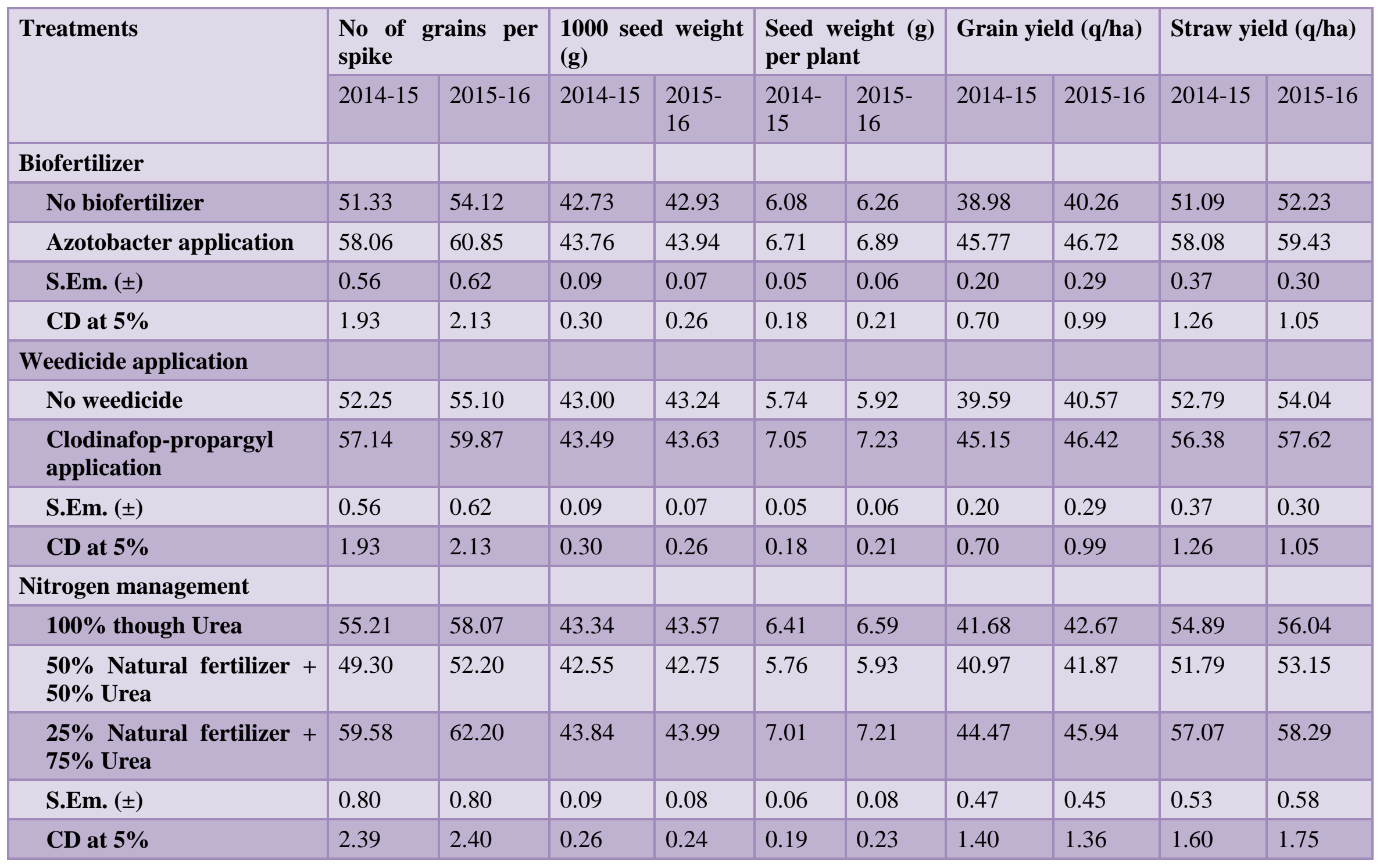


Stimulated vegetative growth of wheat on account of adequate and prolonged supply of essential nutrients in treatments receiving natural fertilizer and micronutrients in addition to the $75 \% \mathrm{~N}$ through urea manifested itself in increased number of effective tillers $\mathrm{m}^{-2}$, number of grains per ear and test weight. The cumulative effect of improved growth, increased dry matter accumulation and yield contributing characters significantly increased the grain yield of wheat. The combined application of $25 \% \mathrm{~N}$ applied by natural fertilizers $+75 \mathrm{~N}$ through urea registered highest grain yield of wheat during both the years of study which was significantly higher than the treatments where $50 \% \mathrm{~N}$ through natural $+50 \%$ through urea fertilizers were applied. The increase in grain and straw yield of wheat might be due to the increased availability of essential nutrients to the crop resulting from the cumulative effect of organic sources of nutrient applied to wheat crop. The harvest index of wheat also recorded a trend similar to grain yield but the treatment differences were short of significance. Chauhan, et al, 2011). Aleminew et al., (2015).

\section{References}

Aleminew, Amare, Adane Legas and Mekonen Misganaw.2015. Yield Response of Bread Wheat to Timing of Urea Fertilizer Application in Eastern Amhara Region. Journal of Biology, Agriculture and Healthcare. Vol.5, No.3, 2015.

Barik and Goswami, (2003). Efficacy of biofertilizers with nitrogen levels on growth, productivity and economics in wheat (Triticum aestivum). Indian Journal of Agronomy 48(2):100-102

Bharat and Karchroo, (2007). Effect of different herbicides on mixed weed flora, yield and economics of wheat (Triticum aestivum) under irrigated conditions of Jammu. Indian Journal of Agricultural Sciences 77(6):383386

Chauhan, D.S., Shrama, R.K., Tripathi, S.C. Kharub, A.S. and Chhokar,R.S. (2011) News paradigm in tillage technology for wheat production. Research Bulletin NO. 8, DWR, Karnal, pp: 16

Gomez, KA and Gomez, AA., 1984. Statistical Procedures for Agricultural Research, (2nd Ed. 1984), John Willey and Sons Inc. New York, USA.

Hamada, SHE., Abdel-Lateef, MF., Abdelmonem, AE., El-Kholy, RMA., Helalia, AAR. (2013). Efficiency of certain clodinafoppropargyl formulations in controlling annual grassy weeds in wheat. Annals of Agricultural Science 58(1): 13-18.

Kim DS, Marshall EJP, Caseley JC and Brain P. 2006. Modelling interactions between herbicide and nitrogen fertilizer in terms of weed response. Weed Research 46 (6): 480-491.

Kumar, S., Angiras, N.N. and Rana, S. S. 2011. Bio-efficacy of clodinafoppropargyl + metsulfuron-methyl against complex weed flora in wheat. Indian Journal of Weed Science 43(3\&4): 195-198.

Malik, R.S., Yadav, Ashok and Kumari, Ramesh. (2013). Indian Journal of Weed Science 45(3): 179-182, 2013

Patel Tejalben, G, Dr. Khushvadan C Patel and Patel Vimal (2017). Effect of integrated nutrient management on yield attributes and yield of wheat (Triticum aestivum L.) International Journal of Chemical Studies 5(4): 1366-1369

Pathak, H., Aggarwal PK, Roetter R, Kalra N, Bandyopadhaya SK, Prasad, S and Van Keulen H. 2003. Modeling the quantitative evaluation of soil nutrient supply, nutrient use efficiency, and fertilizer requirements of wheat in 
India. Nutrient Cycling in Agroecosystems 65: 105-113.

Gawali and Shila, R, P.K. Unni. (2018). Integrated Nutrient Management Approach on Wheat (Triticum aestivum L.) in Vertisols Int. J. Curr. Microbiol. App.Sci. 7(4): 3144-3153

Shehzad, M.A., Muhammad Maqsood, Muhammad Anwar, Haq and Abid Niaz (2012). Efficacy of various herbicides against weeds in wheat (Triticum aestivum L.) African Journal of Biotechnology Vol. 11(4), pp. 791-799

Singh, S, Punia SS, Yadav A and Hooda VS. 2011. Evaluation of carfentrazoneethyl + metsulfuron-methyl against broad leaf weeds of wheat. Indian Journal of Weed Science, 43(1\&2): 12-22.

Singh Samunder, 2007. Role of management practices on control of isoproturonresistant little seed canary grass (Phalaris minor) in India. Weed Technology 21: 339-346.

\section{How to cite this article:}

Deepa, Y.V. Singh and Suruchi Tyagi. 2019. Effect of Biofertilizer, Herbicide Application and Nitrogen Management on Growth, Productivity of Wheat (Triticum aestivum L.). Int.J.Curr.Microbiol.App.Sci. 8(04): 2712-2719. doi: https://doi.org/10.20546/ijcmas.2019.804.315 